\title{
Influence of dextrose on heparinized blood
}

\author{
P. FANTL ANDK. N. MORRIS ${ }^{1}$ \\ From the Baker Medical Research Institute and the Thoracic Surgical Unit, Alfred Hospital, \\ Prahran, Victoria, Australia
}

Since the introduction of total body perfusion (Miller, Gibbon, and Gibbon, 1951 ; Dennis, Spreng, Nelson, Karlson, Nelson, Thomas, Eder, and Varco, 1951) there have been several modifications of pump oxygenators and perfusion techniques, which have been directed towards the reduction or abolition of the amount of heparinized donor blood used to prime the pump oxygenator (Litwak, Slonim, Wisoff, and Gadboys, 1963). As a diluent for heparinized blood, various electrolyte fluids (Panico and Neptune, 1959; Neville, Spinazzola, Banuchi, Scicchitano, and Peacock, 1964), albumin, and low molecular weight dextran (Long, Sanchez, Varco, and Lillehei, 1961) and $5 \%$ dextrose (Zuhdi, Carey, Sheldon, and Greer, 1964) have been suggested.

We were prompted to examine the effects of some of these materials on heparinized blood because of the unexpected appearance of clots in a rotating disc pump oxygenator.

On one occasion the oxygenator had been primed with a mixture of 31 . of blood containing 4 units heparin $/ \mathrm{ml}$., $300 \mathrm{ml}$. of $5 \%$ dextrose, and 2.5 1. Hartmann's solution (Ringer lactate). A considerable amount of clot appeared in the pump oxygenator. A heparin estimation showed the expected concentration of more than 2 units $/ \mathrm{ml}$. of the mixture. A new oxygenator with associated lines was set up and primed in a similar manner. Once again clotting occurred. The operation was abandoned. The result of investigations into the cause of clotting of heparinized blood forms the subject matter of this report. A similar experience has been reported by Bahnson (1964), who attributed the clotting to the effect of ethylene oxide sterilization of the plastic tubing. All of our apparatus was sterilized by autoclaving.

\section{EXPERIMENTS}

As a preliminary investigation, blood containing 4 units heparin $/ \mathrm{ml}$. was incubated at $37^{\circ} \mathrm{C}$. with an equal volume of each of the following solu1 Supported by the Life Insurance Medical Research Fund of
Australia and New Zealand tions : $5 \%$ dextrose, Hartmann's solution, $0.9 \% \frac{\overrightarrow{2}}{x}$ sodium chloride, and varying mixtures of $0.9 \%$ sodium chloride with $5 \%$ dextrose. These materialss were obtained from commercial sources and pres pared freshly from analytical reagents. It was noted that in many instances clots appeared in the reaction mixtures after 30 to 90 minutes incubation.

In order to obtain quantitative results, standardized techniques were developed. In the firs鸟 group of experiments heparinized blood waș centrifuged at $200 \mathrm{~g}$, and the supernatant platelet rich plasma was incubated at $37^{\circ} \mathrm{C}$. for varying periods with the fluids to be tested. Clots, if present, were collected, and their protein conten was determined. The clot yield when platelet-richp plasma was incubated with dextrose solutions of varying concentrations ranged from $23 \%$ to $95 \%$ of the total plasma clot. In contrast, from plasma incubated with $0.9 \%$ sodium chloride, 0 to $30 \%$ of the total plasma clot was obtained. No signifi cant differences could be detected between commercial solutions and those freshly prepared from analytical reagents. It is apparent thaf dextrose solutions caused clotting of heparinized $B$ platelet-containing plasma. The experimentap details have been given elsewhere (Fantl, 1965).

In the second group of experiments, $1,500 \mathrm{ml}$ of whole blood containing 4 units heparin $/ \mathrm{ml}$. obtained from group $\mathrm{O}$ donors, was mixed with $1,500 \mathrm{ml}$. of $5 \%$ dextrose in a rotating disc. oxygenator. Three such experiments were perø formed (Table I). At the beginning of the experitu ment and again after 60 and 120 minutes, samplesu were drawn from the oxygenator for the deter $\frac{\omega}{\sigma}$ mination of fibrinogen, $p \mathrm{H}$, plasma haemoglobiix level, and haematocrit. A careful inspection was: made for the presence of clots.

In experiments 1 and 2 no clots were seen, and only a few very small ones were detected in ex ${ }_{0}^{-}$ periment 3. Progressive determinations of fibrino gen of the mixtures did not show the fall expecteof if clotting had occurred, as was the case after the incubation of platelet-rich heparinized plasma with $5 \%$ dextrose in the test tube. On the cono 
T A B LE I

HEPARINIZED BLOOD-DEXTROSE MIXTURES INCUBATED AT $37^{\circ}$ C. IN A KAY-CROSS DISC OXYGENATOR ${ }^{1}$

\begin{tabular}{|c|c|c|c|c|c|c|c|c|c|c|c|c|}
\hline \multirow[t]{2}{*}{$\begin{array}{c}\text { Incu- } \\
\text { bation } \\
\text { Time } \\
\text { (min.) }\end{array}$} & \multicolumn{3}{|c|}{$\begin{array}{c}\text { Fibrinogen } \\
\text { Plasma- } \\
\text { dextrose } \\
\text { Mixture } \\
\text { (mg. } / 100 \mathrm{ml} \text {.) }\end{array}$} & \multicolumn{3}{|c|}{$\begin{array}{l}p \mathrm{H} \\
\text { of Blood- } \\
\text { dextrose } \\
\text { Mixture }\end{array}$} & \multicolumn{3}{|c|}{$\begin{array}{l}\text { Haemoglobin } \\
\text { of Plasma- } \\
\text { dextrose } \\
\text { Mixture } \\
\text { (mg./100 ml.) }\end{array}$} & \multicolumn{3}{|c|}{$\begin{array}{l}\text { Haematocrit } \\
\text { of Cells in } \\
\text { Blood- } \\
\text { dextrose } \\
\text { Mixture }(\%)\end{array}$} \\
\hline & (1) & (2) & (3) & (1) & (2) & (3) & (1) & (2) & (3) & (1) & (2) & (3) \\
\hline 0 & 84 & 85 & 88 & $7 \cdot 2$ & $7 \cdot 3$ & $7 \cdot 3$ & 0 & 0 & 0 & 29 & 30 & 29 \\
\hline 60 & 92 & 98 & 103 & $7 \cdot 2$ & $7 \cdot 2$ & $7 \cdot 3$ & 28 & 39 & 31 & 37 & & 40 \\
\hline 120 & 100 & 105 & 88 & $7 \cdot 2$ & $7 \cdot 2$ & $7 \cdot 2$ & 73 & 67 & 60 & 4J & 35 & 40 \\
\hline
\end{tabular}

1 To $1500 \mathrm{ml}$. venous blood obtained from three group $\mathrm{O}$ donors was added between 6,000 and 7,500 units heparin and this was mixed with $1,500 \mathrm{ml} .5 \%$ aqueous dextrose. Three experiments were carried out as indicated by the numbers in parentheses.

Blood for (1) was obtained 14 hours, and blood for (2) and (3) approximately one hour, before the experiment. The discs of the oxygenator were coated with silicone grease and rotated at low speed. Carbogen $\left(95 \%\right.$ oxygen, $\left.5 \% \mathrm{CO}_{2}\right)$ was blown into the oxygenator. At the indicated intervals samples were withdrawn and used for the determination of $p \mathbf{H}$. Other specimens were centrifuged at room temperature. Centrifugation at lower temperatures gave considerably higher haemoglobin values in the plasma-dextrose mixtures.

trary, there was a rise in the concentration of fibrinogen in the mixtures associated with an increased cell volume in the haematocrit and a rise in the plasma haemoglobin level. These changes are due to the movement of dextrose and water into the erythrocytes, thereby concentrating plasma and thus increasing the concentration of fibrinogen, the red cell volume, and red cell fragility. The increased red cell fragility was particularly pronounced when samples were centrifuged at $2^{\circ} \mathrm{C}$. to $4^{\circ} \mathrm{C}$. Under these conditions there was extreme haemolysis.

It was not thought practicable to repeat these experiments in a non-siliconized oxygenator since our apparatus has been coated with silicone over long periods.

Therefore in the third group of experiments, heparinized blood was incubated in glass tubes under varying experimental conditions with $0.3 \mathrm{M}$ dextrose, $0.3 \mathrm{M}$ sodium lactate, $0 \cdot 167 \mathrm{M}$ sodium lactate, Hartmann's lactate solution, and $0.15 \mathrm{M}$ sodium chloride (Table II). These experiments show that, as with platelet-rich plasma, clotting occurred when whole blood containing 4 units heparin $/ \mathrm{ml}$. was incubated with $5 \%$ dextrose. The amount of clot obtained varied with the different samples of blood from $17 \%$ to $87 \%$, averaging $53 \%$. Clotting was increased when stainless steel rods were rotated in the blood mixture. When glass rods were used clotting was reduced by coating the tube and the rod with silicone. When heparinized blood was incubated with isotonic sodium lactate solution $(0.3 \mathrm{M})$ or with Hartmann's lactate solution, clot formation was also noted. When incubation was carried out with isotonic sodium chloride $(0.15 \mathrm{M})$ clot formation occurred to the extent of 0 to $32 \%$, averaging $8.5 \%$.

Dextrose-induced clotting could be prevented by increasing the heparin concentration to 8 units $/ \mathrm{ml}$. blood.

In those experiments in which whole blood was incubated with $5 \%$ dextrose, there was a rise in

T A B L E I I

CHANGES IN HEPARINIZED BLOOD MIXED WITH DILUENTS IN GLASS TUBES

\begin{tabular}{|c|c|c|c|c|c|}
\hline Composition of Mixture ${ }^{1}$ & $\begin{array}{l}\text { Contact of } \\
\text { Blood Mixture }\end{array}$ & $\begin{array}{l}\text { Incubation } \\
\text { Time (min.) }\end{array}$ & $\begin{array}{l}\text { Loss of } \\
\text { Fibrinogen } \\
\text { (\% total } \\
\text { fibrinogen) }\end{array}$ & $\begin{array}{c}\text { Haemoglobin } \\
\text { after } \\
\text { Incubation } \\
\text { (mg. } 100 \mathrm{ml} \text {. } \\
\text { plasma } \\
\text { diluent } \\
\text { mixture) }\end{array}$ & $\begin{array}{c}\text { Haematocrit } \\
\text { (\% cells } \\
\text { after } \\
\text { incubation of } \\
\text { blood } \\
\text { diluent } \\
\text { mixture) }\end{array}$ \\
\hline $\begin{array}{l}\text { I Whole blood with } 4 \text { units heparin } 100 \mathrm{ml} \text {. } \\
0.3 \mathrm{M} \text { dextrose }\end{array}$ & $\begin{array}{l}\text { Pyrex glass tube and } \\
\text { rod }\end{array}$ & 75 & 53 & 70 & 50 \\
\hline $\begin{array}{l}\text { Ia Whole blood with } 4 \text { units heparin } \mathrm{ml} .0 .3 \mathrm{M} \\
\text { sodium lactate } \\
\text { Ib Whole blood with } 4 \text { units heparin } \mathrm{ml} .0 \cdot 15 \mathrm{M} \\
\text { sodium chloride }\end{array}$ & $\begin{array}{l}\text { Pyrex glass tube and } \\
\text { rod } \\
\text { Pyrex glass tube and } \\
\text { rod }\end{array}$ & 75 & $\begin{array}{l}35 \\
8 \cdot 5\end{array}$ & $\begin{array}{l}0 \\
0\end{array}$ & $\begin{array}{l}23 \\
23\end{array}$ \\
\hline $\begin{array}{l}\text { Ia Whole blood with } 4 \text { units heparin ml. } 0.3 \mathrm{M} \\
\text { dextrose }\end{array}$ & $\begin{array}{l}\text { Pyrex glass tube, } \\
\text { stainless steel rod } \\
\text { stationary }\end{array}$ & 120 & 31 & ++ & - \\
\hline $\begin{array}{l}\text { IIb Whole blood with } 4 \text { units heparin ml. } 0.3 \mathrm{M} \\
\text { dextrose }\end{array}$ & $\begin{array}{l}\text { Pyrex glass tube, } \\
\text { stainless steel rod } \\
\text { rotating }\end{array}$ & 120 & 82 & $+t+$ & - \\
\hline $\begin{array}{l}\text { III Whole blood with } 4 \text { units heparin } \mathrm{ml} .0 .3 \mathrm{M} \\
\text { dextrose }\end{array}$ & $\begin{array}{l}\text { Siliconized tube and } \\
\text { rod }\end{array}$ & 130 & 0 & 86 & 56 \\
\hline $\begin{array}{l}\text { IV Whole blood with } 8 \text { units heparin ml. } 0.3 \mathrm{M} \\
\text { dextrose }\end{array}$ & $\begin{array}{l}\text { Pyrex glass tube and } \\
\text { rod }\end{array}$ & 60 & 0 & ++ & 66 \\
\hline
\end{tabular}

1 Equal volumes of heparinized blood approximately one hour after collection and the diluents of the indicated concentrations were mixed in graduated centrifuge tubes, and rods of approximately $2 \mathrm{~mm}$. diameter were inserted. Incubation was carried out in a water bath at $37^{\circ} \mathrm{C}$. The clots were collected on rods which were removed after incubation, and the fluid blood mixture was centrifuged for 20 min. at $3,000 \mathrm{~g}$. preferably at room temperature. 
cell volume in the haematocrit and plasma haemoglobin content of the mixtures similar to that seen in the experiments carried out in the rotating disc oxygenator. No increase in haematocrit or plasma haemoglobin level occurred when heparinized blood was incubated with isotonic sodium lactate or isotonic sodium chloride.

\section{DISCUSSION}

A number of compounds, namely, dextrose, fructose, mannose, 2-desoxyglucose, mannitol, saccharose, and glycine, can cause clot formation in heparinized plasma (Fantl, 1964). In the present investigation it has been shown that clotting can be induced in heparinized blood by dextrose and sodium lactate. The process requires all the components of the blood-clotting system which are essential for thrombin formation, and physicochemical factors which influence clotting play a significant part in the activation process. Clotting of mixtures of heparinized blood with dextrose or sodium lactate occurred to a significant degree in contact with glass or stainless steel. Clotting was increased by the agitation of stainless steel rods in the mixture, and it was abolished when the surfaces of the tubes and rods were siliconized.

Heparin prevents clotting if present in adequate concentration, and the anticoagulant activity depends also on a plasma component heparin cofactor (anti-thrombin II). When blood containing 4 units heparin $/ \mathrm{ml}$. is mixed with an equal volume of aqueous fluids the concentration of heparin drops to 2 units $/ \mathrm{ml}$. This concentration is adequate to prevent clotting under normal conditions, but when blood mixtures contained $0.3 \mathrm{M}$ dextrose or $0.3 \mathrm{M}$ sodium lactate, clotting occurred after incubation. The anticoagulant activity of heparin is apparently reduced. Heparin itself is not lost but heparin co-factor is diminished. Either glucose activates some step in the clotting process to produce sufficient thrombin to cause clotting, or dextrose counteracts heparin co-factor activity and thus reduces the anticoagulant activity of the heparin system (Fantl, 1965). It is possible to overcome the clot-promoting activity of dextrose by siliconizing the apparatus or by increasing the heparin concentration.

In addition to its clot-promoting effect, dextrose has an adverse effect on heparinized blood by causing an increase in red cell volume, increased red cell fragility, and increased levels of plasma haemoglobin. The action of dextrose on the erythrocytes is independent of the clot-promoting action. The erythrocyte damaging effect occurs in both siliconized and non-siliconized containers.
The increased fragility of erythrocytes exposed to $\stackrel{\vec{F}}{\vec{\rho}}$ $5 \%$ dextrose has been observed by Mainardi, Bhanganada, Mack, and Lillehei (1964), who흠. reported that rapid haemolysis occurred in mix $-\overline{\bar{D}}$ tures of equal parts of fresh heparinized blood and@ $5 \%$ dextrose.

Morris, Kinross, and Stirling (1965) found that the plasma haemoglobin level in blood mixtures in:primed pump oxygenators averaged $27 \mathrm{mg} . / 100 \vec{\omega}$ ml. when $5 \%$ dextrose was used as a diluent. If the concentration of dextrose was lowered by partial $\vec{x}$ substitution with saline, the mean value of plasmaĩ haemoglobin in the mixture was $13 \mathrm{mg} . / 100 \mathrm{ml}$. Five per cent. dextrose is slightly hypotonic $(0.28 \mathrm{\omega}$ M). Even when isotonic dextrose $(0.3 \mathrm{M})$ was used $N$ erythrocyte fragility was very pronounced, parti-으 cularly when the mixture was centrifuged at $2^{\circ} \mathrm{C}$. to $4^{\circ} \mathrm{C}$.

Although the above experiments have not revealed the cause of clotting which initiated the $\overrightarrow{0}$ study, facts have been observed which make it $\mathrm{c}$ reasonable to ask the question, 'Is $5 \%$ dextrose a safe, simple, efficient, and physiological ... . blood prime?' (Zuhdi et al., 1964). The exposure of heparinized blood to $5 \%$ dextrose will certainly result in some haemolysis. It may also result in some fibrin formation.

The clot-promoting activity of dextrose is re- $\overrightarrow{\vec{B}}$ lated to its concentration, which will fall rapidly when infused into the patient and therefore will probably not cause clotting during bypass. However, if before bypass blood-dextrose mixtures are in contact with an unsiliconized surface of an oxygenator and the discs are rotated, clotting will occur. This may not be macroscopically visible 3 but might produce sufficient fibrin particles to be injurious to the patient. Similar considerations apply to sodium lactate.

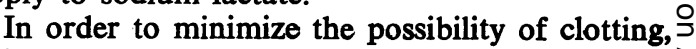
it is advised that the concentration of dextrose or $\frac{7}{2}$ sodium lactate used in the priming of pump oxygenators be reduced by the substitution of $0.9 \%$ o sodium chloride, which gives protection against haemolysis and possible clotting. We have hesitated $N$ to use isotonic sodium chloride only because of $\omega$ the load this would give to the patient. For this reason we are currently using a solution containing $0.45 \%$ sodium chloride and $2.5 \%$ dextrose. It is also recommended that the mixture of blood ${ }^{+}$ and diluent be kept in the oxygenator for as short ${ }^{0}$ a period as is practical before commencing bypass, $\stackrel{\circ}{\mathbb{D}}$

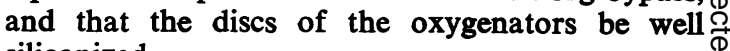
siliconized.

We acknowledge gratefully the assistance of the Red Cross, blood bank of Victoria. Mr. I. E. McInnes, 음 
M.B., B.S., F.R.C.S., helped in the oxygenator experiments, and Mrs. V. Carson, M.Sc., assisted with the biochemical determinations. The Commonwealth Serum Laboratories, Parkville, Victoria, supplied the heparin preparations free of preservatives.

\section{REFERENCES}

Bahnson, H. T. (1964). Discussion. J. thorac. cardiovasc. Surg., 47, 78. Dennis, C., Spreng, D. S., Nelson, G. E., Karlson, K. E., Nelson, R. M., Thomas, J. V., Eder, W. P., and Varco, R. L. (1951) Development of a pump-oxygenator to replace the heart and lungs ; an apparatus applicable to human patients, and application to one case. Ann. Surg., 134, 709.

Fantl, P. (1964). Induced coagulation of heparinised blood. I. Active compounds. Aust. J. exp. Biol. med. Sci., 42, 491. (1965). Clotting in heparinised plasma. Il. Underlying reactions. Ibid., 43, 45.

Litwak, R. S., Slonim, R., Wisoff, B. G., and Gadboys, H. L. (1963). Homologous-blood syndrome during extracorporeal circulation in man. II. Phenomena of sequestration and desequestration. New Engl. J. Med., 268, 1377.
Long, D. M., jr., Sanchez, L., Varco, R. L., and Lillehei, C. W. (1961) The use of low molecular weight dextran and serum albumin as plasma expanders in extracorporeal circulation. Surgery, 50, 12.

Mainardi, L. C., Bhanganada, K., Mack, J. D., and Lillehei, C. W. (1964). Hemodilution in extracorporeal circulation. Comparative study of low molecular weight dextran and 5 percent dextrose. Ibid., 56, 349 .

Miller, B. J., Gibbon, J. H., and Gibbon, M. H. (1951). Recent advances in the development of a mechanical heart and lung apparatus. Ann. Surg., 134, 694

Morris, K. N., Kinross, F. M., and Stirling, G. R. (1965). Hemolysis of blood in the pericardium : the major source of plasma hemoglobin during total body perfusion. J. thorac. cardiovasc. Surg., 49, 250.

Neville, W. E., Spinazzola, A. Banuchi, F., Scicchitano, L. P., and Peacock, H. (1964). Clinical experience with buffered Ringer's lactate solution for total prime for the disc oxygenator during cardiopulmonary bypass. Ibid., 48, 101.

Panico, F. G., and Neptune, W. B. (1959). A mechanism to eliminate the donor blood prime from the pump-oxygenator. Surg. Forum, $10,605$.

Zuhdi, N. Carey J., Sheldon, W., and Greer, A (1964). Comparative merits and results of primes of blood and 5 per cent dextrose in water for heart-lung machines. Analysis of 250 patients. $J$. thorac. cardiovasc. Surg., 47, 66. 